\title{
Measurement of the Plasma Free Thyroxine Level as a Test of Thyroid Function
}

\author{
MAURICE WELLBY,* M.D., M.SC., M.C.P.A. ; M. W. O'HALLORAN,† M.SC.
}

Brit. med.f., 1966, 2, 668-670

The concept that the small amount of unbound or free thyroxine $\left(\mathrm{T}_{4}\right)$ is the factor in determining the true thyroid status of the individual (Robbins and Rall, 1957) has been supported by evidence in recent studies (Christensen, 1960 ; Sterling and Hegedus, 1962 ; Lee et al., 1964 ; Ingbar et al., 1965). Nevertheless, the measurement of either the plasma protein-bound iodine (P.B.I.) or the resin uptake of labelled triiodothyronine $\left(\mathrm{T}_{3}\right)$ should suffice to confirm a diagnosis in most cases of primary myxoedema and primary thyrotoxicosis (Wellby and O'Halloran, 1966).

However, in many conditions in which there is an abnormality in $T_{4}$ binding by serum proteins there are of ten deviations from the normal in both P.B.I. and resin uptake of $T_{3}$ without associated changes in the thyroid status (Robbins and Rall, 1960). The serum level of free $T_{4}$ should be of value in diagnosing the thyroid status of patients with such conditions.

The procedures for the estimation of free $T_{4}$ utilize either dialysis (Sterling and Hegedus, 1962 ; Ingbar et al., 1965) or Sephadex filtration (Lee et al., 1964) to separate the free from the protein-bound $\mathrm{T}_{4}$.

Clark and Horn (1965) have used the mathematical product of P.B.I. and resin uptake of $T_{3}$ as a "free $T_{4}$ index," and justify this approach on the mathematical relationship that exists between free $T_{4}$, P.B.I., and resin uptake when certain assumptions are fulfilled.

The purpose of this paper is to investigate the comparative value of two methods of assessing the free $T_{4}$ level of serumnamely, the Sephadex-filtration technique of Lee et al. (1964) and the "free $T_{4}$ index" of Clark and Horn (1965).

\section{Methods}

The normal subjects were volunteers or outpatients without evidence of serious disease. The patients with thyroid disorders were restricted to those with untreated primary thyrotoxicosis or myxoedema. The thyroid status was assessed on the usual clinical criteria, and invariably independently of the results of the P.B.I. or resin uptake of $\mathrm{T}_{3}$. Studies were made also on patients with abnormal thyroid-binding proteins in the serum. Patients with a clinical diagnosis of either nephrosis or macroglobulinaemia, or who were currently being treated with androgen or high doses of corticosteroids, or who had serum albumin levels of less than $3.6 \mathrm{~g} . / 100 \mathrm{ml}$., were classified as having decreased thyroid-binding. Subjects undergoing normal pregnancy or who were being treated with oestrogencontaining drugs were classified as having increased thyroidbinding. The uptake of ${ }^{13}{ }^{1} \mathrm{I}$ by the thyroid gland and the response to therapy were used where applicable. Blood was collected and heparinized and the plasma separated under iodine-free conditions. The plasma was stored frozen until the day of assay.

The P.B.I. was determined by the alkaline incineration procedure of Acland (19.57). Assays were performed in dupli-

\footnotetext{
* Clinical Biochemist, Queen Elizabeth Hospital, Woodville, South
}

+ Biochemist, Queen Elizabeth Hospital, Woodville, South Australia. cate and the results discarded if the differences exceeded 0.5 $\mu \mathrm{g} . / 100 \mathrm{ml}$. The resin uptake of $\mathrm{T}_{3}$ was performed in duplicate according to modifications (Taylor et al., 1964) of the method of Woldring et al. (1961). The results, expressed as a percentage of a pool of normal plasma, were discarded if the differences between duplicates exceeded $10 \%$ of their mean value. The "free thyroxine index" of Clark and Horn (1965) was calculated from the mathematical product of P.B.I. and resin-uptake percentage divided by 100 .

The Sephadex filtration method of estimating free $T_{4}$ was performed by modifications of the method of Lee et al. (1964). The ${ }^{131} \mathrm{I}_{-} \mathrm{T}_{4}$ of specific activity of 25 to $40 \mu \mathrm{Ci} / \mu \mathrm{g}$. was sent by air freight from Abbott Laboratories, and on receipt stored at $4^{\circ} \mathrm{C}$. and used for no more than 10 days after receipt. Approximately $0.5 \mu \mathrm{Ci}$ of ${ }^{131} \mathrm{I}-\mathrm{T}_{4}$ is added to duplicate $1-\mathrm{ml}$. aliquots of plasma. The enriched plasma is placed on a small column of Sephadex G-25 (coarse bead type), and the proteinbound $\mathrm{T}_{4}$ is washed through with $0.5 \mathrm{M}$ saline and collected in a $100-\mathrm{ml}$. volumetric flask. The volume is adjusted to $100 \mathrm{ml}$., and 3-ml. aliquots are counted in a scintillation detector fitted with a well-type crystal. The free $T_{4}$ remains on the Sephadex, and the intact column is wrapped in parafilm, placed in a counting-tube, and counted. Sufficient countingtime is allowed to collect 5,000 to 10,000 counts above background.

The free $T_{4}$ value as $\mathrm{m} \mu \mathrm{g}$. of $\mathrm{T}_{4} / 100 \mathrm{ml}$. of plasma is calculated from:

$$
\text { Free } \mathrm{T}_{4}=\frac{\mathrm{F} \times \text { P.B.I. }}{0.654 \times \mathrm{B}}
$$

where $F=$ net count rate of Sephadex-bound ${ }^{131} I$

$\mathrm{B}=$ net count rate of protein-bound ${ }^{13}{ }^{1} \mathrm{I}$

P.B.I. is expressed in $\mathrm{m} \mu \mathrm{g} . / 100 \mathrm{ml}$. plasma.

The percentage of total $T_{4}$ present in the free state is calculated from $F \div B \times 100$, assuming the protein-bound $T_{4}$ to approximate the total $\mathrm{T}_{4}$.

\section{Results}

Euthyroid Subjects and Patients with Primary Thyroid Diseases (Table I).- There was no overlap between the three groups in the P.B.I. values but there was the expected overlap in resin-uptake values, particularly between the hypothyroid and the euthyroid groups. There was a similar overlap in the free $T_{4}$ percentages: for the hypothyroid group values ranged from 0.025 to 0.078 , for the euthyroid group from 0.047 to 0.085 , and for the hyperthyroid group from 0.081 to 0.144 . There was no overlap in the free $T_{4}$ index or in the values for Sephadex-free $T_{4}$ concentration (Table I). There was a highly significant $(P<0.001)$ correlation between the results obtained with the "free $T_{4}$ index" and the Sephadex-bound $T_{4}$ in the three groups of subjects without binding abnormalities (Fig. 1).

Subjects with Binding Abnormalities.-The results (except for the hyperthyroid subjects in pregnancy or on oestrogen therapy) are shown in Table II and Fig. 2. The normal ranges for $T_{3}$, "free $T_{4}$ index," and Sephadex-free $T_{4}$ concentration 
are derived from the mean \pm 2 standard deviations of a normal population of 150 subjects, including the 23 normal subjects of this investigation. Fig. 2 shows at a glance that neither the P.B.I. nor the resin uptake of $\mathrm{T}_{3}$ is accurate in diagnosing the euthyroid status of subjects with binding abnormalities. The resin-uptake value was outside the normal range in $57 \%$ of the subjects with decreased binding and in $63 \%$ with increased binding. The P.B.I. was incorrect in $71 \%$ of subjects with decreased and in all of the subjects with increased binding. By contrast, both the "free $T_{4}$ index" and the free $T_{4}$ concentration values were within the normal range in all subjects with decreased binding. In the subjects with increased binding the "free $\mathrm{T}_{4}$ index" and the free $\mathrm{T}_{4}$ concentration were correct on 75 and $87.5 \%$ of occasions respeetively.

There were eight subjects who were clinically thyrotoxic and who, in addition, had increased plasma protein $\mathrm{T}_{4}$ binding due either to pregnancy or to oestrogen therapy. The values found were as follows : resin uptake, a range of 76.0 to $105.8 \%$ of the normal pool (normal range, 76 to 117 ) ; P.B.I. range from 10.3 to $18.0 \mu \mathrm{g} . / 100 \mathrm{ml}$. (normal 3.8 to 7.0 ) ; " free $\mathrm{T}_{4}$ index," range from 9.2 to 17.9 (normal 3.4 to 6.8 ) ; and for free $\mathrm{T}_{4}$ concentration, range from 9.3 to $18.6 \mathrm{~m} \mu \mathrm{g} . / 100 \mathrm{ml}$. (normal 3.4 to 7.3).

\section{Discussion}

The mean free $T_{4}$ concentration in normal plasma estimated with Sephadex was found in the present study to be $5.4 \mathrm{~m} \mu \mathrm{g}$.

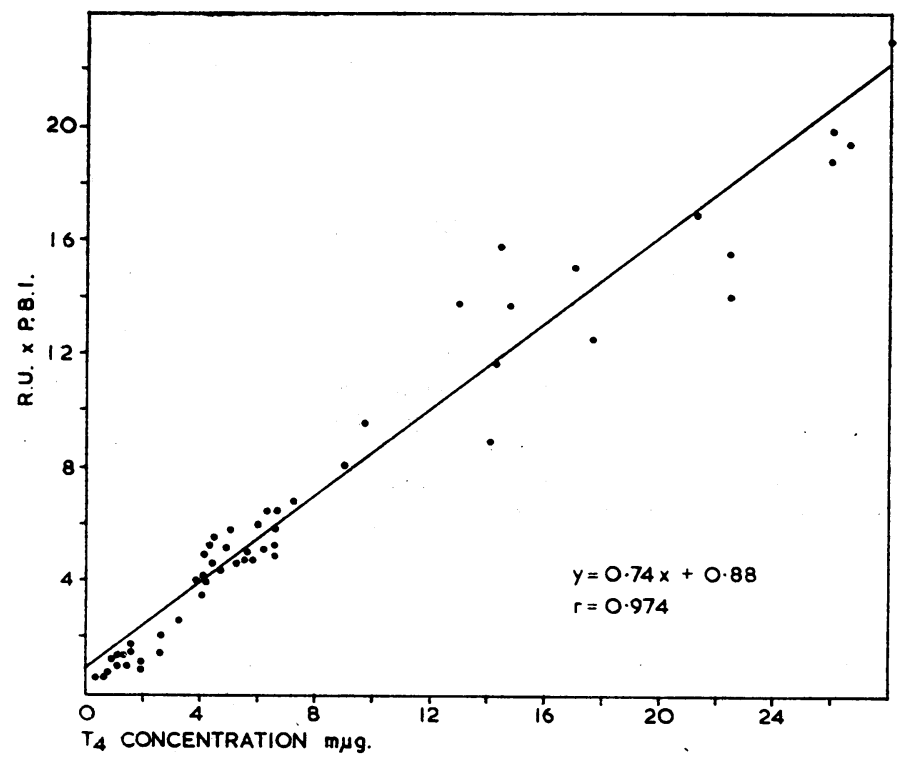

FIG. 1.-Correlation of results for "free thyroxine index" and for free thyroxine concentration ( $\mathrm{m} \mu \mathrm{g} . / 100 \mathrm{ml}$ ) in hyperthyroid, euthyroid, and of $\mathrm{T}_{4}$ per $100 \mathrm{ml}$. of plasma, which is between the value of 3.1 $\mathrm{m} \mu \mathrm{g} . / 100 \mathrm{ml}$. found with Sephadex by Lee et al. (1964) and the value of $9.9 \mathrm{~m} \mu \mathrm{g} . / 100 \mathrm{ml}$. of Sterling and Hegedus (1962) and $9.1 \mathrm{~m} \mu \mathrm{g} . / 100 \mathrm{ml}$. of Liewendahl and Lamberg (1965) obtained by dialysis through cellophane. Ingbar (1958) reported a figure of $4.0 \mathrm{~m} \mu \mathrm{g} . / 100 \mathrm{ml}$. in a series of 87 normal patients, using the technique of dialysis followed by a second dialysis combined with ion exchange to purify the free $T_{4}$ from contaminating inorganic iodine. As Lee et al. (1964) suggest, one possible reason for differing results is a dissociation of a small amount of $T_{4}$ from the T.B.P.T. ${ }_{4}$ complex, either before or during the assay process. Lee et al. assume that, as the values with Sephadex are less than those obtained with a dialysis procedure, then the Sephadex does not cause any dissociation of $T_{4}$. However, this assumption is valid only if the recoveries of free $\mathbf{T}_{4}$ in the Sephadex method are near $100 \%$, and if the values obtained in the dialysis procedure are not artifactually elevated by contaminating radioactive inorganic iodide. When special precautions are taken to eliminate this contamination the values obtained are considerably reduced (Ingbar et al., 1965).

The present investigation confirms others (Sterling and Hegedus, 1962 ; Liewendahl and Lamberg, 1965 ; Ingbar et al., 1965) in demonstrating clear-cut differences between the total free $T_{4}$ values obtained in euthyroid, hyperthyroid, and hypothyroid subjects. This observation supports the theory that it is the unbound form of $T_{4}$ which crosses the cell membrane and determines the physiological thyroid status of the individual. However, there seems little point in performing a free $T_{4}$ esti-
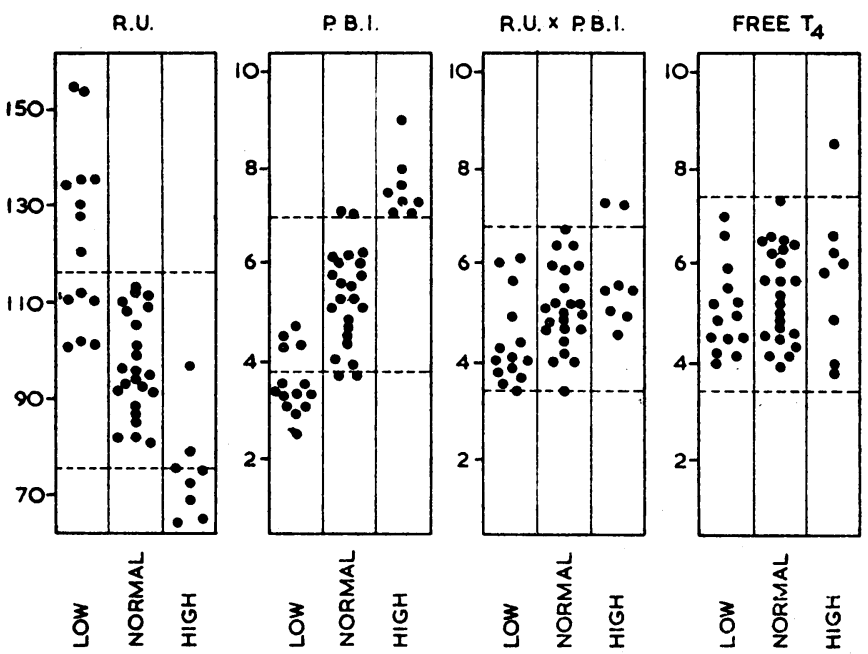

FIG. 2.-Results for resin uptake (R.U.) (percentage of normal), proteinbound iodine (P.B.I., $\mu$ g./100 ml.), "free thyroxine index" (R.U.X P.B.I.), and free thyroxine concentration ( $\mathrm{m} \mu \mathrm{g} . / 100 \mathrm{ml}$.) in normal subjects and in patients with decreased (low) and increased (high) plasma thyroid-binding proteins. The dotted lines indicate the limits of the normal ranges as explained in the text.

TABle I.-Values (Mean and Standard Deviations) for Thyroid Function Tests in Normal Subjects and in Patients with Untreated Primary Thyroid Disorders

\begin{tabular}{|c|c|c|c|c|c|c|c|c|}
\hline \multicolumn{4}{|c|}{ Group } & $\begin{array}{l}\text { P.B.I. } \\
(\mu \mathrm{g} . / 100 \mathrm{ml})\end{array}$ & $\begin{array}{c}\text { Resin Uptake } \\
\text { (Percentage of Normal) } \\
\end{array}$ & $\begin{array}{c}\text { Free } \mathrm{T}_{4} \text { Index } \\
\left(\left[\mathrm{T}_{3} / 100\right] \times \text { P.B.I. }\right)\end{array}$ & $\begin{array}{c}\text { Free } \mathrm{T}_{4} \text { Concentration } \\
(\mathrm{m} \mu \mathrm{g} . / 100 \mathrm{ml} .)\end{array}$ & $\begin{array}{c}\text { Free } T_{4} \\
\text { Percentage }\end{array}$ \\
\hline $\begin{array}{l}\text { Hypothyroid (15)... } \\
\text { Euthyroid (23) } \\
\text { Hyperthyroid (15) }\end{array}$ & $\begin{array}{l}\cdots \\
\therefore\end{array}$ & $\because$ & $\begin{array}{l}\cdots \\
\cdots\end{array}$ & $\begin{array}{r}1.89 \pm 0.69 \\
5.33 \pm 0.98 \\
11.06 \pm 2 \cdot 40\end{array}$ & $\begin{array}{r}72.5 \pm 12.1 \\
96.5 \pm 10 \cdot 2 \\
131.4 \pm 16.8\end{array}$ & $\begin{array}{r}1.34 \pm 0.51 \\
5.09 \pm 0.84 \\
15.37 \pm 3.90\end{array}$ & $\begin{array}{r}1.71 \pm 0.73 \\
5.43 \pm 0.99 \\
19.01 \pm 6.25\end{array}$ & $\begin{array}{l}0.05 \pm 0.01 \\
0.07 \pm 0.01 \\
0.11 \pm 0.02\end{array}$ \\
\hline
\end{tabular}

Figures in parentheses indicate number of subjects in group.

TABLE II.-Values (Mean and Standard Deviations) for Thyroid Function Tests in Normal Subjects and in Patients with Abnormalities in Thyroxine Binding by Plasma Protein

\begin{tabular}{|c|c|c|c|c|c|c|c|c|}
\hline \multicolumn{4}{|c|}{ Group } & $\begin{array}{l}\text { P.B.I. } \\
(\mu \mathrm{g} . / 100 \mathrm{ml} .)\end{array}$ & $\begin{array}{c}\text { Resin Uptake } \\
\text { (Percentage of Normal) }\end{array}$ & $\begin{array}{c}\text { Free } \mathbf{T}_{4} \text { Index } \\
\left(\left[\mathbf{T}_{3} / 100\right] \times \text { P.B.I. }\right)\end{array}$ & $\begin{array}{c}\text { Free } T_{4} \text { Concentration } \\
(\mathrm{m} \mu \mathrm{g} . / 100 \mathrm{ml} .)\end{array}$ & $\begin{array}{c}\text { Free } T_{4} \\
\text { Percentage }\end{array}$ \\
\hline $\begin{array}{l}\text { Decreased binding (14) } \\
\text { Normal ( } 23 \text { )..ंing }(\ddot{8})\end{array}$ & $\begin{array}{l}\cdots \\
\cdots\end{array}$ & $\because$ & $\begin{array}{l}\cdots \\
\therefore\end{array}$ & $\begin{array}{l}3.58 \pm 0.67 \\
5.33 \pm 0.98 \\
7.57 \pm 0.64\end{array}$ & $\begin{array}{r}123.7 \pm 18.2 \\
96.6 \pm 10.2 \\
75.1 \pm 10.6\end{array}$ & $\begin{array}{l}4.41 \pm 0.91 \\
5.09 \pm 0.84 \\
5.71 \pm 0.97\end{array}$ & $\begin{array}{l}5.06 \pm 0.90 \\
5.43 \pm 0.99 \\
5.86 \pm 1.60\end{array}$ & $\begin{array}{l}0.095 \pm 0.02 \\
0.07 \pm 0.01 \\
0.05 \pm 0.01\end{array}$ \\
\hline
\end{tabular}

Figures in parentheses indicate number of subjects in group. 
mation in order to confirm a diagnosis of uncomplicated, untreated thyrotoxicosis or myxoedema when this could be accomplished by performing P.B.I. and resin uptake of $T_{3}$ estimations (Wellby and O'Halloran, 1966).

In the presence of iodine contamination, the free $\mathrm{T}_{4}$ concentration is invalidated, as a P.B.I. is needed for its calculation, whether this be by a direct Sephadex method or the arbitrary "free $T_{4}$ index." Possibly the percentage of free $T_{4}$ which is derived entirely from measurements of radioactivity could be of value in this situation. It would be necessary first to determine whether the property of the Sephadex in partitioning the free from the protein-bound $T_{4}$ is interfered with by excess inorganic or organic iodine. According to the results of this investigation, the value of estimating the percentage of free $T_{4}$ is minimized by the large overlap between the myxoedema and the normal group of subjects, which reflects the overlap in resin uptake of $\mathrm{T}_{3}$ between myxoedematous patients and normal subjects. There is no significant overlap, however, between the normal and the thyrotoxic group. In view of the good correlation observed between the "free thyroxine index" (resin uptake $\times$ P.B.I.) and

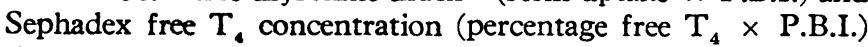
the correlation between resin uptake and percentage free $T_{4}$ is not unexpected.

The free $T_{4}$ assay has an even greater value in diagnosing the thyroid status of patients with disturbances in the binding of $\mathrm{T}_{4}$ by plasma proteins. The inaccuracies of the P.B.I. and the resin uptake in such subjects are now well documented. There are few data in the literature as yet on the values for free $T_{4}$ concentration in these conditions. Lee et al. (1964) found normal concentrations in three euthyroid pregnant subjects. A small though significant diminution in the free $T_{4}$ concentration in pregnancy has been found with dialysis procedures (Sterling and Hegedus, 1962 ; Ingbar et al., 1965). It is apparent from the present study that either the "free $T_{4}$ index" or the free $T_{4}$ concentration in euthyroid patients with binding abnormalities produces values within the range found for euthyroid subjects without binding abnormalities. This confirms and extends the findings of Clark and Horn (1965), who found the "free $T_{4}$ index" to be in the normal range in 23 euthyroid pregnant subjects and in four euthyroid patients with nephrosis. The value of free $T_{4}$ estimation is further demonstrated by the elevated values found in each of the six pregnant thyrotoxic subjects. Other studies from this laboratory have shown that the "free T. index" of Clark and Horn (1965) is of value in assessing the thyroid status of patients who have had thyrotoxicosis treated with ${ }^{131} \mathrm{I}$ (Wellby and O'Halloran, 1966).

The usefulness of the free $T_{4}$ assay in investigating the thyroid status of patients with binding abnormalities having been established, the question of which is the more useful technique to perform remains to be answered. One advantage of the Sephadex method is that it provides data on the percentage of $\mathrm{T}_{4}$ in the free form as well as the free $\mathrm{T}_{4}$ concentration, and this could be useful in studying the changes occurring in thyroid hormone kinetics in the circulation of patients undergoing treatment for thyrotoxicosis, in the study of patients with familial disturbances in the thyroid-binding proteins, and in other situations.

Although the "free $T_{4}$ index" is only an arbitrary index of free $T_{\star}$ it has the distinct advantage that it utilizes techniques that should exist in the average diagnostic laboratory. Furthermore, this investigation demonstrates that there is very good correlation between the "free $T_{4}$ index" and a Sephadex estimation of free $T_{4}$. It seems justifiable to conclude that the "free $T_{4}$ index" is a useful addition to the established methods in the diagnosis of thyroid disorders.

\section{Summary}

Comparative studies on two methods of estimating the free thyroxine $\left(\mathrm{T}_{4}\right)$ level in plasma are described, one being the Sephadex-gel filtration technique and the other the mathematical product of protein-bound iodine (P.B.I.) and the resin uptake of triiodothyronine $\left(\mathrm{T}_{3}\right)$-that is, the "free $\mathrm{T}_{4}$ index" of Clark and Horn.

The results of free $T_{4}$ assays on plasma from normal subjects are: Sephadex method, range 3.6-7.4 m $\mu$ g. ; "free $T_{4}$ index," 3.4-6.8 units. The values obtained in hypothyroid and in thyrotoxic patients are sharply differentiated from those in euthyroid subjects.

Studies were made also on eight euthyroid subjects with increased plasma protein binding of $\mathrm{T}_{4}$ due to pregnancy or oestrogen therapy and in 14 euthyroid subjects with decreased binding secondary to hypoalbuminaemia or nephrosis. Whereas a high percentage of the P.B.I. and the resin-uptake values were outside the normal ranges, both methods of estimating the free $T_{4}$ levels produced normal results with only one exception. Elevated levels were found in the six thyrotoxic subjects with binding abnormalities.

It is concluded that free $T_{4}$ assays are useful in assessing thyroid function, particularly in patients with $T_{\star}$ binding abnormalities in the plasma, where the interpretation of P.B.I. and resin uptake of $T_{3}$ can be, difficult.

We are grateful for Professor B. S. Hetzel's advice and his reading of the manuscript. We are indebted to the medical staff of the Queen Elizabeth Hospital for access to patients, and to Miss Margaret Carmen for valuable technical assistance. The ${ }^{131}$ I-labelled thyroxine and triiodothyronine were provided through the courtesy of the Committee on Radio-Isotopes of the National Health and Medical Research Council of Australia and financed by the National Welfare Fund.

\section{RBFERENCES}

Acland, J. D. (1957). Biochem. 7., 66, 177.

Christensen, L. K. (1960). Acta med. scand., 166, 133.

Clark, F., and Horn, D. B. (1965). ¥. clin. Endocr., 25, 39.

Ingbar, S. H. (1958). Endocrinology, 63, 256.

Ingbar, . Elin Invest., 44, 1679 .

Lee, N. D., Henry, R. J., and Golub, O. J. (1964). J. clin. Endocr., 24, 486.

Liewendahl, K., and Lamberg, B. A. (1965). Ibid., 25, 991.

Robbins, J., and Rall, J. E. (1957). Recent Progr. Hormone Res., 13, 161 .

Sterling K (1960). Physiol. Rev., 40, 415.

Taylor, K., Winikoff, D., and Davies, W. (1964). Aust. Ann. Med., 13, 240.

Wellby, M. L., and O'Halloran, M. W. (1966). Ibid., 15, 116. Wold (Kbh.), 37, 607. 